\title{
MICROCLIMATIC RESEARCH IN THE SLOVAKIAN SHOW CAVES
}

\section{MIKROKLIMATSKE RAZISKAVE V SLOVAŠKIH TURISTIČNIH JAMAH}

\author{
JAN ZELINKA $^{1}$
}

${ }^{1}$ Slovak Caves Administration, Hodžova 11, SK-031 01 LIPTOVSKÝ MIKULÁŠ, SLOVAKIA, phone: ++421 44 5536201, e-mail: zelinka@ssj.sk

Prejeto / received: 26. 3. 2002 


\section{Izvleček}

UDK: 551.584:551.44(437.6)

\section{Jan Zelinka: Mikroklimatske raziskave v slovaških turističnih jamah}

Prispevek obravnava delo Oddelka za varstvo jam pri Upravi za slovaške jame na področju speleoklimatskega monitoringa slovaških turističnih jam od 1996 dalje. Monitoring je usmerjen na podrobno merjenje osnovnih parametrov klimatskih procesov (temperatura, relativna vlažnost zraka, kondenzacija, gibanje zraka, zračni pritisk itd.) v turističnih jamah v obdobju najmanj enega leta. Bistvo pridobljenega znanja pomaga pri varovanju jam in v praksi turističnim jamam omogoča boljše razumevanje geoekosistema, določa vpliv obiskovalcev, čas trajanja regeneracije jame in oceni možne negativne posledice. Rezultate monitoringa uporabljamo za določanje kapacitete konkretne jame, omejitve števila obiskovalcev, organizacijo vodenja in druge potrebne ukrepe. Meritve v predstavljenih jamah smo opravljali glede na prioriteto: področja svetovne dediščine, ledene jame, naravna zveza zračnih mas s površinsko klimo, možne nevarnosti - vse v zvezi z uporabo in delovanjem jame. Tehnična oprema kot tudi raziskovalna metodologija sta $\mathrm{v}$ prispevku podrobno predstavljeni.

Ključne besede: speleologija, jamski monitoring, mikroklima, turistična jama, Slovaška.

\section{Abstract}

UDC: $551.584: 551.44(437.6)$

\section{Jan Zelinka: Microclimatic Research in the Slovakian Show Caves}

The paper deals with the activities of the Cave Protection Department of the Slovak Caves Administration in the field of speleoclimatic monitoring in the Slovakian show caves since 1996. The monitoring is concentrated on detail survey of basic climatic parameters processes (temperature, relative air humidity, dew point, air velocity, atmospheric pressure etc.) in by now studied show caves during minimally one year. The essence of obtained knowledge is to enhance cave protection in the practice of show caves, better understand the geoecosystems; determine visitors' influence, the period of regeneration and evaluation of possible negative influences. The results of the monitoring are used for determining the carrying capacity of individual caves, limits for visitors, guiding the manageiant and other necessary measures. Presented caves were surveyed by priorities like: World Heritage site, ice caves, natural air mass communication with surface climate, potential threats - all in relation to cave utilization and operation. Technical eqqipment, as well as research methodology are described in detail in the paper.

Key words: speleology, cave monitoring, microclimate, show cave, Slovakia. 


\section{INTRODUCTION}

Every country, where the karst territories and caves represent significant nature phenomena, is dealing with their legislative protection as well as the practical care. This is the case in Slovenia, Austria, Hungary, France, but also in the USA and in other countries. The primary aim is to obtain a skilled surveillance, which could guarantee the preservation and prevent damaging of the original conditions in caves. In Slovakia, this mission is assured by the Slovak Caves Administration, which was established by the Ministry for the Environment of the Slovak Republic as a professional organization to meet this purpose.

The present protection and practical care for the show caves in Slovakia is done on the basis of the latest scientific knowledge, which can be obtained by using up-to-date and financially expensive equipment. This equipment is operated and the results interpreted by skilled professional employees of the Slovak Caves Administration. These comparatively demanding processes are solved also in cooperation and experience exchange with international experts and institutions.

The caves lost their previous legal protection after the transformation processes and legislative changes in Slovakia in the first half of the nineties. This increased the pressure for handing over the caves to municipalities and their commercial utilization, often without securing the basic conditions of safety, hygiene and especially their protection. The interest was naturally concentrated only on lucrative caves mainly the present show caves. Five of the twelve show caves in Slovakia are inscribed on the World Natural Heritage List of UNESCO: the Ochtinská Aragonite Cave, Jasovská Cave, Gombasecká Cave, Domica Cave and the Dobšinská Ice Cave. This fact became the main argument to include caves in the state property in the amendment of the Constitution of the Slovak Republic approved by the Parliament on February 23, 2001.

The latest approach of the Slovak Caves Administration in relation to the microclimatic monitoring started to realize in connection to its new Statute. It was endorsed and came in effect on April 1, 1996 in relation to the Act of the National Council of the Slovak Republic No. 287/1994 of the Legal Codes, on Nature and Landscape Protection. The important change, as compared to its previous version, is the regulation that guarantees the cave protection also to genetically connected caves of the show caves. We need to emphasize that all the caves under supervision of the Slovak Caves Administration are, in the meaning of the Act, designated the national nature monuments with the highest - fifth level of protection. (A proposal for amendment of the Act on Nature and Landscape Protection, in connection to the Constitution amendment, is being prepared at present. It should deal with the problems of caves more consistently).

\section{PROBLEMS STATING}

The beginnings of the detailed microclimatic observations in Slovakian caves date back to the period of discovery of the Dobšinská Ice Cave in 1870, and its successive tourist utilization. Later, the attention was concentrated also on other caves, in order to know their basic microclimatic characteristics. The highest attention, however, was always put on the ice caves, which were considered the most sensitive from the changes and influencing their dominant secondary filling points of view. 
Methods and measuring equipment used for such observations and research corresponded to that time level of knowledge and possibilities. Following the development of measuring technique and the latest scientific approaches in spheres connected to speleoclimate, we gradually reached the level, which we realize in our conditions within the framework of our possibilities.

The aim of the monitoring in the Slovakian show caves is to gain knowledge of the detail course of basic speleoclimatic characteristics like temperature, relative air humidity, dew point, air velocity, atmospheric pressure, $\mathrm{CO}_{2}$ contents and others. The substance of such knowledge lies not only in better understanding the studied cave geosystems, but also determining of the anthropogenic influences on their changes, stability and regeneration possibility. In the practice of show caves, the microclimatic monitoring results are among the most important data when determining their carrying capacity, limits for the number of visitors, guidelines for their utilization and operation, technical intervention and other measures.

Coming out from the financial demands and amount of the equipment needed for microclimatic monitoring realization, as well as from the minimal time period, we set down the following priorities for measuring in the so far monitored caves: inscription on the World Heritage List of UNESCO, ice caves, natural communication of air with outside climate, potential threats etc. In many cases there is a combination of several criteria.

\section{CHARACTERISTICS OF THE MONITORING TECHNIQUE}

The monitoring itself was done by using the automatic measuring and registration stations BABUC/A, which are produced by LSI company, seated in Milan, Italy. BABUC is a set of devices, probes, accessories and software for data capture, display, recording and processing of great amount of technical measurements in integrated environment. It also enables transfer of recorded data to PC. It is possible to record values at as frequently as several seconds' interval, according to the number of connected sensors. Thanks to this we could pursue very detailed measurements. The limiting factor for the range and length of one measuring series is the memory capacity of the datalogger, which is $64 \mathrm{kB}$. This enables to save about 20,000 items. The disadvantage of the equipment is its high failure rate at low temperatures and high humidity; and when measuring in long period it is also the necessity of connection to the mains, when the blackouts can cause the loss of data and disturbing the continuity.

Since the above-mentioned BABUC measuring devices are gradually worn down after the long time usage in the caves, we are preparing their replacement with newer types.

During the last year and especially in the ice caves, new devices for recording the temperature and humidity proved reliable. These so called "Black Boxes" are manufactured by the Czech firm Comet Systems ltd, seated in Rožňov pod Radhoštěm. Thanks to their small dimensions $(93 \times 61 \times 23 \mathrm{~mm})$, own energetic source with minimum life for 3 years, measuring range from -30 to $+70^{\circ} \mathrm{C}$, and from 0 to $100 \%$ as for the relative humidity, memory capacity for 16,000 items, interval of recording from 1 minute to 24 hours, communication with PC, it is possible to install them anywhere in the cave without disturbing the aesthetics value and also without cable connection to the electric power. 


\section{SELECTION OF MONITORING SITES}

We choose the monitoring sites so that we could characterize the changes of cave climate in all important parts of the cave. The sites should reflect the extreme difference of studied parameters and give a representative picture on climatic regime of the individual cave. We must take into account the number of measuring devices available, when selecting the sites. In case of BABUC measuring stations, it is also a question of connection to the mains. At the same time, we continuously measure and record the climatic values in front of the cave entrance.

We practice two variants of sensors installation. In the first case, we place the sensors in socalled breathing zone of visitors, at the height of $1.3 \mathrm{~m}$ above the cave floor. In the second case, we place the sensors in various levels of the vertical profile between bottom and ceiling of the studied space.

\section{THE WAY OF MONITORING}

We use two basic ways of observation of speleoclimatic regime and its influencing by visitors, which we always apply on the whole monitoring system. The first, basic monitoring, we practice with 10 minutes' interval of data recording (when the cave is open to the public), or with one-hour interval (when the cave is closed to the public). The aim of this monitoring is to record the variability of speleoclimatic changes during longer time periods. In case of dripstone caves with stabile microclimate, it is one year minimally. In case of ice caves and aragonite cave, it takes a longer time (minimum 5 years).

Except for the basic monitoring, we are also performing the so-called micro-regime observations in periods with maximum number of visitors. Their aim is to record the detailed courses of changes induced by the visitors during their stay in the cave. We set the recording interval to 10 seconds in this case. Simultaneously, we record the number of visitors in each group and the time they spent at the measuring site. We use the total daily number of visitors from the SCA information system for evaluation of the long-term observations.

\section{SYNOPSIS OF THE LATEST MICROCLIMATIC OBSERVATIONS}

\section{Bystrianska Cave, Demänovská Cave of Liberty, Gombasecká Cave, Jasovská Cave}

The speleoclimatic monitoring in the above written caves was done within the framework of the supportive project 0364-B 5 "Monitoring of the Natural Environment in Karst Territories" for the PHARE I - EC/HEA/10S1 project "Protection of Natural Resources in Karst".

The project was organisationally secured by the Ministry for the Environment of the Slovak Republic, and realized by the firm SKOV ltd, Bratislava.

Year of proceeding: $1995-96$

Monitored climatic parameters: temperature, relative air humidity, air velocity, atmospheric pressure, $\mathrm{CO}_{2}$ contents, Radon and its daughter products, ionisation.

Goal: to find out and describe the changes of basic climatic parameters of the cave environment during speleotherapeutic procedures. 
Conclusions: performing the speleotherapeutic stays in the monitored caves does not cause irreversible changes of speleoclimatic conditions; the results in all cases confirm a relatively high thermodynamic stability of the cave climate.

\section{MICROCLIMATIC MONITORING REALIZED BY THE SLOVAK CAVES ADMINISTRATION}

\section{Ochtinská Aragonite Cave}

Reasons for carrying out the monitoring: The speleoclimatic conditions of the cave are one of the decisive factors of the present state of its genesis, which influence the stability of its unique secondary filling, mostly the aragonite. Aragonite was created under specific hydrochemical and microclimatic conditions in closed underground spaces and in three periods of time, for which its different forms are characteristic. The mechanism of threatening the aragonite resides in corrosion of its surface from possible water vapour condensation, which is enriched by $\mathrm{CO}_{2}$ breathed out by the visitors. The present time creation of aragonite was hypothetically excluded due to anthropogenic influence. The realized monitoring ought to have confirmed or exclude these opinions.

The cave has been inscribed on the World Heritage List of UNESCO since December 1995.

Proceeding term: $1^{\text {st }}$ period from May 20 to November 13, 1996

Goal: to find out the changes and development of the speleoclimatic regime of the system in connection to the cave visitors

Technical equipment used for monitoring: automatic measuring and registration station BABUC/ A, LSI, Milan, Italy

Conclusions: we acquired and processed in computer more than 650,000 data items during the monitoring process. According to the temperature and humidity regimes, we can divide the cave in two parts - the entrance part, which is relatively colder and more humid, and the central and rear part, which is warmer and drier. The speleoclimatic changes caused by visitors are more intensive in comparatively smaller and at the same time warmer spaces, while the maximum intensity of influence was identified in the ceiling part of the cave space, where aragonite decoration occurs. All the changes caused by the visitors have a strictly demarcated duration. Relatively quick regeneration of original air characteristics takes place after the visitors' leaving from monitored sites. The substantial part of the regeneration phase doesn't usually take longer than one hour. No important accumulations of influence were recorded during the monitoring. The observation results indicate that during the changes caused by the visitors' presence the relative humidity in the breathing zone rises as compared to the higher and lower situated air layers, however no water vapours condensation happens here neither during the presence of visitors nor after their leaving in the phase of air cooling.

The maximum number of visitors in one group was reduced from the original 80 to 30-35 people, with the 15 minutes' interval of admission, because of significant changes in temperature and relative humidity caused by the visitors' presence. 
Proceeding term: $2^{\text {nd }}$ period year 1997

Goal: to find out the annual course of basic microclimatic parameters of the cave and verification of the microclimatic changes amplitude after the radical modification of the entrance schedule

Technical equipment used for monitoring: automatic measuring and registration station BABUC/ A, LSI, Milan, Italy

Conclusions: the long-term monitoring realized through the whole year showed, that in spite of the visiting season, the natural course of thermodynamic changes is preserved in the cave. The visitors don't influence the course of neither minimal nor average daily temperatures, the long-term changes (summer culmination) of which don't correspond to the intensity of attendance.

The correctness of reduction the number of visitors per one admission was confirmed. Adjustment of admission regime minimized the changes of pursued parameters and radically shortened the regeneration time of cave spaces after the visitors' leaving.

\section{Year of proceeding: 1997}

Goal: mineralogical research of the cave

It was carried out in cooperation with the Geological Institute of the Czech Academy of Sciences in Prague and the University of Sydney, Australia.

Conclusions from the microclimatic point of view: the research disproved the hypothesis from the researches realized in 1990 and confirmed the formation of aragonite also under the present conditions. Aragonite is formed on sediments and iron ochres, which did not attract a special attention before. Their main component is goethite, which arises from weathering of ankerites and siderites. Ochres contain 47-56 volume percent of water on an average. They have the ability to release and absorb water vapour. Since they cover a substantial part of the cave, they represent a significant exchanger of humidity, by which they markedly contribute to stabilizing of the cave climate.

\section{Years of proceeding: 1998, 2000}

Goal: verification of the increased occurrence of $\mathrm{CO}_{2}$ in the cave air measured in the past, by various methods and continuous observation in extreme periods of cave attendance.

The research realized in cooperation with the Institute of Geotechnics of the Slovak Academy of Sciences in Košice.

Technical equipment used for monitoring: $1^{\text {st }}$ period - air collection into polythene two-ply sacks with aluminum foil and successive processing in the Orset device;

$2^{\text {nd }}$ period - continuous air collection by non-disperse infrared (NDIR) catalyst of $\mathrm{CO}_{2}$, Guardian plus Edinburgh Sensors Ltd. type, recorded by Extech Datalogger.

Conclusions: the maximum of measured $\mathrm{CO}_{2}$ values reaches $40 \%$ of the highest permissible concentration, which is $6,477 \mathrm{ppm}$, and this amount doesn't mean a risk either to the people working in the cave or to the visitors. The increased amount of $\mathrm{CO}_{2}$ depends on local sources (decay, decomposition, carbonate oxidation etc.), and its stabile values are supported by zero or laminar air velocity caused by the visitors. The increased values of $\mathrm{CO}_{2}$ are directly caused by the number of visitors. The source of $\mathrm{CO}_{2}$ is not in the waters and soils occurring in the cave. 
Year of proceeding: August, September 2000

Goal: comparing the concentration of $\mathrm{CO}_{2}$ in 11 show caves of Slovakia and 12 of the Czech Republic in the period of culmination of its values in the caves.

Research was realized in cooperation with the Agency for Nature and Landscape Protection of the Czech Republic.

Technical equipment used for monitoring: Dräger Multiwarn II SED with IR CO2 sensor

Conclusions: constant values of $0.24 \%$ concentration of $\mathrm{CO}_{2}$ were confirmed in the cave, which makes evident the entire isolation of the cave and the surface.

\section{Year of proceeding: 2001}

Goal: finding out the influence of visitors on the air temperature changes at $0.2 \mathrm{~m}$ elevation above the floor and $0.3 \mathrm{~m}$ under the ceiling in the space with the highest occurrence of aragonite in the cave, which the visitors pass two times during their tour. The contact sensors recorded also the changes of surface temperature of the rock and aragonite decoration

Technical equipment used for monitoring: four-channel datalogger for temperature L 0141 „Black box” for temperature probes with resistance sensor Ni 1000/6180 ppm, COMET SYSTEM ltd, Czech Republic.

Conclusions: it is a long-term monitoring, not yet finished. By now, the influence of visitors also to the changes of rock and aragonite temperature with a relatively quick return to average values was recorded.

\section{Dobšinská Ice Cave}

Reasons for monitoring: the character of glaciation ranks this cave among the most important ice caves in the world, which is in Europe accentuated by its location outside the Alps region. The ice surface is $9.772 \mathrm{~m}^{2}$ large and the volume of ice reaches $110.132 \mathrm{~m}^{3}$. The greatest thickness of ice reaches $26.5 \mathrm{~m}$. The cave has a natural air communication with the surface, which significantly influences its thermo-dynamical regime, character and formation of secondary ice fillings. The regime of the course of basic microclimatic parameters was considerably influenced by anthropogenic interventions in the past. One of the most significant results of research, done lately and finished in 1986, specified its temperature balance.

The cave was inscribed on the World Heritage List of UNESCO on November 20, 2000.

Years of proceeding: $1^{\text {st }}$ period - from July 1997 to May 1999 - cave microclimate from July 1997 to January 2001 - outside climate

Goal: long-term observation of the course of the basic cave microclimatic parameters (dry and wet temperature, relative humidity, dew point, air velocity, atmospheric pressure) in six different parts of the cave and finding out the extent of the outside temperature influence. Reviewing of the visitors' influence on the microclimate change.

Technical equipment used for monitoring: automatic measuring and registration stations BABUC/A, LSI, Milano, Italy.

Year of proceeding: $2^{\text {nd }}$ period - from January 2001, with a long-term perspective

Technical equipment used for monitoring: dataloggers for temperature and humidity L 3120 „Black box” and four-channel dataloggers for temperature L 0141 „Black box” for tempera- 
ture probes with resistance sensor Ni 1000/6180 ppm, manufacturer COMET SYSTEM ltd, Czech Republic.

Goal: except for the above stated, extended measurements that include monitoring of temperature stratification in $25 \mathrm{~m}$ high air profile, where the temperature changes of rock surface and forehead of the underground glacier are monitored.

Conclusions: the $1^{\text {st }}$ period is now at the stage of evaluation. The BABUC/A measuring stations proved not to be suitable for measurements in cold environment. Besides that, they were frequently damaged by the influence of lightning bolts, which caused significant blackouts, and damages on the devices. The data already processed and evaluated confirmed a considerable variability of microclimatic changes in various parts of the cave, but also a significant influence of the outside climate on the parts of the cave that are near the entrance and surface. In spite of relatively large volume of cave spaces, the short but significant influences of the microclimate by visitors were recorded. The number of visitors during four months of its opening to the public reaches 100,000 . We changed the installed lighting for "cold" sodium lamps and shortened the lighted sections in connection to the cave microclimate. Also the reconstruction of original show path in the cave was done, by which the morphology of cave spaces was returned to its original state as it was at the time of discovery. This was immediately reflected in the change of thermodynamic characteristics of the cave that aimed at the values, which we consider natural, and also in increased formation of vertical ice forms to the shape they were known at the time of cave discovery.

The change of microclimate, increment or decrement of ice, its sublimation, as well as accelerated frost weathering of the bedrock are mainly influenced by outside climatic conditions. The most distinct influence has the amplitude of temperature fluctuation, temperature inversions, number and length of frost days and days with snow cover. The intensive summer rainfall appears to be the most significant parameter influencing the cave temperatures and character of ice filling. That's why we started cooperation with the Hydrometeorological Institute of the Slovak Academy of Sciences, which regularly observes these parameters and delivered us the measured values of outside climate also for the past years. Detailed evaluation of the cave microclimatic monitoring requires a study of all factors, influencing the given ecosystem; that's why we don't include them in this paper.

We concluded an agreement with the Wroclav University in Poland to realize more detailed study of the microclimate and glaciological research of the cave. We are going to start our own joint research of the Dobšinská Ice Cave phenomenon at the beginning of 2002.

\section{Domica Cave}

Reasons for monitoring: it is one of the most significant caves in the territory of the Slovak Karst. Except for important speleo-archaeological values, it is typical by large cave spaces and richness of speleothems, among which shields, drums, rimstone lakes, onion-like stalactites and pagoda-like stalagmites are typical. Corrosion and erosion activities of underground waters of Styx and Domicky Brook had the main share on creation of this cave. Their intermittent occurrence in the cave also at the present time, as well as different temperature and amplitude (mainly of the Domicky Brook), contributed significantly to the temperature, relative humidity and air velocity changes. The detailed continuous microclimatic monitoring of 
the cave is related to the results of its hydrological and hydrochemical monitoring realized in 1995 and consequently to the hydrological monitoring from 1997-98. At present, the monitoring is under way in three different parts of the cave and is compared with the outside climatic values.

The Domica Cave was together with the Baradla Cave (in Hungary), with which they form a joint cave system, inscribed on the World Heritage List of UNESCO.

Year of proceeding: 2001, to be continued on a long-term basis

Goal: long-term observation of changes of the basic microclimatic parameters in the cave in relation to its hydrological regime, as well as to the values of the outside climate.

Technical equipment used for monitoring: automatic measuring and registration stations BABUC/A, manufacturer LSI, Milan, Italy; since November 2001 in combination with temperature and humidity dataloggers L 3120 „Black box”, manufacturer COMET SYSTEM 1td, Czech Republic.

Conclusions: since the monitoring started only this year and will continue for a long time, no conclusions can be derived yet.

\section{Driny Cave}

\section{Reasons for realizing the monitoring:}

Years of proceeding: from April 1998 to March 1999

Goal: to find out the course of the basic microclimatic parameters of the cave climate throughout one year and determining its changes and progress in relation to cave attendance.

Technical equipment used for monitoring: automatic measuring and registration stations BABUC/A, manufacturer LSI, Milan, Italy.

Conclusions: taking into account the acquired knowledge as for the temperature, humidity and air flux dynamics changes, we can divide the cave into a more stabile part that is more distant from its entrance and a dynamic part, which is located in spaces near the entrance and in surrounding parts. These parts naturally communicate with the outside climate, which influences them moreover in the winter season. Also the changes in cave operation show here. They are caused, except for the visitors, who pass these spaces twice, by opening the entrance doors. The changes caused by the visitors are not strong. In spite of them, the natural annual course of thermodynamic changes is preserved in the cave. The cave is characteristic by a quick regeneration capacity. We didn't record any negative influences of the visitors on the cave climate.

\section{Važecka Cave}

Reasons for realizing the monitoring: the entrance part of the cave was known for a long time. The more distant parts, which are now open to the public, were discovered by digging the passage that remained open and thus enabled to influence the values of original microclimate significantly and with visible negative consequences on speleothems and bedrock. The cave is characteristic by high values of Radon volume activity.

Years of proceeding: 1999-2000 
Goal: finding out the annual course of speleoclimatic parameters, the dependence between static and dynamic part of the cave, influence of outside climate to accelerated frost weathering of the bedrock in its entrance parts and influence of visitors on their changes and changes of Radon contents.

Technical equipment used for monitoring: automatic measuring and registration stations BABUC/A, manufacturer LSI, Milan, Italy, PRASSI Portable Radon Gas Surveyor mod. 5S, Silena, Milan, Italy, thermometer Checktemp, Portugal

Conclusions: it was unequivocally proved that the entrance parts are strongly ventilated through the Discovery Passage and the temperature amplitude fluctuates here in the course of the year between -5.7 to $+8.4^{\circ} \mathrm{C}$. The volume activity of Radon reaches around 3,500 Bq. $\mathrm{m}^{-3}$ thanks to the intensive flux of air masses. All values of watched microclimatic parameters are stabilized within the $100 \mathrm{~m}$ distance from the entrance and show only small fluctuations throughout the year. These are, thanks to the small volume of cave spaces, significantly influenced by the visitors' impact, but this change lasts only very shortly and is delimited in time. After that, all the values return back to the average almost immediately. The highest values of Radon volume activity (up to 24,500 Bq. $\mathrm{m}^{-3}$ ) are recorded in the most distant parts from the entrance, which are at the same time the warmest $\left(6.8^{\circ} \mathrm{C}\right.$ on an average) ones. They are decreased by whirling the air by visitors and by Radon absorption in their clothes during the visiting season. Artificial barriers were built to prevent the direct exchange of air masses between surface and underground in the winter season, by which the further degradation of secondary cave fillings from weathering and frost was prevented.

\section{Demänovská Ice Cave}

Reasons for realizing the monitoring: the cave is characteristic by very segmented geomorphological shapes, which together with entrances in several elevations above the sea level cause considerable dynamics of air masses interchange. This is an unusual phenomenon from the point of view that the lowest parts of the cave are glaciated all the year round.

Year of proceeding: since October 2001, long-term monitoring

Goal: detail knowledge of the complex microclimatic regime of the cave system in all its different parts as for the temperature, as well as in the vertical air profiles; evaluation of its changes dynamics in relation to the secondary ice filling of the cave.

Technical equipment used for monitoring: dataloggers for temperature and humidity L 3120 „Black box” and four-channel dataloggers for temperature L 0141 „Black box” for temperature probes with resistance sensor Ni 1000/6180 ppm, manufacturer COMET SYSTEM ltd, Czech Republic.

Conclusions: since the monitoring was started only this year and will last for a long time, no conclusions can be formulated so far. 


\section{CONCLUSIONS}

On the basis of the present knowledge from realization of the microclimatic monitoring within the conditions of the Slovak Caves Administration, it was confirmed that if we want to protect the unique natural creations, which the caves certainly represent, we must firstly know them in detail. This requires understanding not only one phenomenon, but also all mutual linkages in studied geosystems. This aspect calls for the necessity of a multidisciplinary approach in applying the latest scientific knowledge and using of the latest up-to-date technical equipment. In experience, it means the summary of the financially and knowledge demanding processes, making the experience interchange and international cooperation necessary. The correctness of our knowledge, which was already applied in experience, was confirmed by repeated monitoring. That's why we count with using the knowledge from monitoring in practical care, surveillance over operation and utilization, regulation of their attendance and planning of technical and other interventions in caves in the future. The main mission of monitoring is an effective protection of caves and their preservation in original conditions.

\section{LITERATURE}

KLAUČO, S. A KOL., 1996: Monitoring prírodného prostredia v krasových oblastiach. Atmochemický a mikroklimatický monitoring speleoterapeuticky využívaných jaskýň na Slovensku. Manuskript, SKOV Bratislava.

KLAUČO, S. A KOL., 1996: Speleoklimatický monitoring Ochtinskej aragonitovej jaskyne. Záverečná správa, SKOV Bratislava.

KLAUČO, S., FILOVÁ, J. \& ZELINKA, J., 1997: Speleoklimatický monitoring Ochtinskej aragonitovej jaskyne. Aragonit, 2, 3-5.

KLAUČO, S., FILOVÁ, J. \& ZELINKA, J., 1998: Vplyv návštevnosti na speleoklímu Ochtinskej aragonitovej jaskyne. Výskum, využívanie a ochrana jaskýn̆, Zborník referátov z vedeckej konferencie, Liptovský Mikuláš, 75-86.

ZELINKA, J., FILLOVÁ, J. \& KLAUČO, S., 1997: Speleoclimatic monitoring of Ochtinska Aragonit Cave. Protection and Medical Utilisation of Karst Environment, Banska Bystrica, 31-32.

ZELINKA, J., 1999: Speleoklimatic monitoring of the Driny Cave. Výskum, využívanie a ochrana jaskýň, Zborník referátov z vedeckej konferencie, Liptovský Mikuláš, 168-179. 


\section{MIKROKLIMATSKE RAZISKAVE V SLOVAŠKIH TURISTIČNIH JAMAH}

\section{Povzetek}

Vse jame pod nadzorstvom Uprave slovaških jam so zakonsko zaščitene kot naravni spomeniki najvišjega reda. Zaščita jam se izvaja tudi na osnovi spremljanja dejavnikov, ki vplivajo na ranljivost jam. Eden od teh je jamska mikroklima, ki jo opazujejo z namenom, da bi razumeli njeno dinamiko in določili vpliv človeka nanjo. $\mathrm{V}$ turističnih jamah se mikroklimatski podatki upoštevajo pri določanju števila obiskovalcev in načrtovanju tehničnih ter ostalih posegov v jami.

Prva opazovanja jamske mikroklime na Slovaškem so zabeležena že leta 1870. Danes za opazovanje uporabljajo avtomatske zapisovalnike podatkov različnih proizvajalcev. Ti omogočajo stalno spremljanje parametrov kot so temperatura, vlaga, tlak, hitrost zračnih tokov, vsebnost $\mathrm{CO}_{2}$ itd.

Dolgočasovne spremembe jamske klime spremljajo z meritvami, ki trajajo od enega do pet let. V turističnih jamah v času obiskov merijo z 10 minutnim intervalom, sicer pa $\mathrm{z}$ urnim intervalom. Senzorje namestijo bodisi v območju dihanja obiskovalcev (1,3 m visoko), bodisi na različnih višinah jamskega profila.

Z opisanimi metodami spremljajo mikroklimo v številnih jamah na Slovaškem. Na osnovi teh meritev so uvedli več ukrepov za zaščito jam. Tako so v Ochtinski aragonitni jami zmanjšali število obiskovalcev v skupini z 80 na 30-35 in uvedli večji časovni razmak med skupinami. Znaten vpliv obiskovalcev na jamsko mikroklimo so izmerili tudi v Dobšinski ledeni jami. V več jamah pa se klima, ki jo prisotnost skupine obiskovalcev zmoti, zelo hitro vrne v stabilno - naravno stanje. 